慶應義塾大学学術情報リポジトリ

Keio Associated Repository of Academic resouces

\begin{tabular}{|c|l|}
\hline Title & On the logic of historical explanation \\
\hline Sub Title & \\
\hline Author & 神山, 四郎(Koyama, Shiro) \\
\hline Publisher & 三田哲學會 \\
\hline Publication year & 1965 \\
\hline Jtitle & 哲學 No.46 (1965. 2),p.D1- D1 \\
\hline JaLC DOI & \\
\hline Abstract & \\
\hline Notes & Abstract \\
\hline Genre & \\
\hline URL & $\begin{array}{l}\text { https://koara.lib.keio.ac.jp/xoonips/modules/xoonips/detail.php?koara_id=AN00150430-0000004 } \\
6-0520\end{array}$ \\
\hline
\end{tabular}

慶應義塾大学学術情報リポジトリ(KOARA)に掲載されているコンテンツの著作権は、それぞれの著作者、学会または出版社/発行者に帰属し、その権利は著作権法によって 保護されています。引用にあたっては、著作権法を遵守してご利用ください。

The copyrights of content available on the KeiO Associated Repository of Academic resources (KOARA) belong to the respective authors, academic societies, or publishers/issuers, and these rights are protected by the Japanese Copyright Act. When quoting the content, please follow the Japanese copyright act. 


\section{On the Logic of Historical Explanation}

\section{Shiro Koyama}

(1) Idealists (Collingwood etc.) insist on the view that the historical understanding has its own principle essentially different from that of science. (2) Covering-law-theorists (Hempel etc.) positively deny this view, saying that the scientific explanation has only an axiom that the explanandum must be deduced from the universal law, and the historical explanation is also regulated by this axiom. Then, (3) Reactionists (Dray etc.) strongly oppose to this theory of (2).

If (3) denies (2), (3) reaffirms (1). But, can it be true? Igor Kon says that the theory of Dray is identified with the idiographism of New-Kantian school. I cannot agree with this. It is impossible that Dray as a positivist makes his way for accepting an empathic understanding of the individual facts. It seems to me that it was a little careless of him to have failed to see the function of generalization, which is habitual to historians, in order to defend the validity of individual narratives against the charge of Hempelian theory.

Dray, with his motive explanation given in contextual reference on the level of ordinary language, could save the historical explanation from the pit of explanation sketch into which Hempelian causal explanation falls. But he unconditionally admits any standpoint on which any historian gives a reason to his subject matter selected among various historical facts. Then he makes meaningless the question what is a true cause of history.

After all, my opinion is that the theory of (3) in fact cannot be fundamentally reactionary to that of (2), but either of them can be used as a complementary tool of thinking to each other. For, although they started from different levels of analysis, they can be said to have been aiming at the same goal. 